MSC 30-04

DOI: $10.14529 / \mathrm{mmp} 190101$

\title{
COMPARISON OF QUASI-STATIONARY AND NON-STATIONARY SOLUTIONS OF ELECTROCHEMICAL MACHINING PROBLEMS APPLYING TO PRECISION CUTTING WITH PLATE ELECTRODE-TOOL
}

\author{
V.P. Zhitnikov ${ }^{1}$, N.M. Sherykhalina ${ }^{1}$, S.S. Porechny ${ }^{1}$ \\ ${ }^{1}$ Ufa State Aviation Technical University, Ufa, Russian Federation \\ E-mails: zhitnik@mail.ru,n_sher@mail.ru, porechny@mail.ru
}

\begin{abstract}
The quasi-stationary problem for modelling the process of electrochemical cutting with a plate electrode-tool is formulated. The formulation of the problem is based on the use of a stepwise function of current efficiency from the current density. Thus three areas with various conditions are formed on the machined surface. The usual stationarity condition is used in the area of high current densities. In the area of low current densities the dissolution is absent and the initial form of the boundaries remains. In the intermediate zone, the current density at each point is equal to the critical value. The presence of boundary conditions on each section of the machined surface allows to formulate a boundary problem for the analytical function of the complex variable and to find the shape of the boundary at any moment, regardless of the background. The solutions of quasi-stationary and non-stationary problems are compared, and the range of existence of quasi-stationary solutions is found.

Keywords: electrochemical shaping; stepwise function; quasi-stationary model; error estimation.
\end{abstract}

\section{Introduction}

Problems of modelling of electrochemical machining (ECM) has been solved by many authors. However, more attention was paid to the study of stationary solutions with different current efficiency dependencies on the current density (a part of the current participating in the reaction of metal dissolution) [1-14]. The solution of non-stationary problems allows to determine many additional parameters that are not described by a stationary solution, including the time of establishing of a stationary process with a given accuracy. However, the need for computational resources for solving such problems is much greater [15-21].

In the simulation of many processes a non-stationary problem can be simplified by using the quasi-stationary approximation. In this case, a solution for every moment of time can be found independently of the others. There is no need to decrease the time step to maintain the accuracy and stability. But it is necessary to study the range of applicability of the quasi-stationary approximation within the limit of errors.

The choice of current efficiency $\eta(j)$ on current density $j$ is offered in [22] and justified on the basis of analysis of experimental data in [14]

$$
\eta(j)= \begin{cases}\eta_{0}, & j>j_{1}, \\ \forall \eta \in\left[0, \eta_{0}\right], & j=j_{1}, \\ 0, & j<j_{1}\end{cases}
$$

Вестник ЮУрГУ. Серия «Математическое моделирование

и программирование» (ВестникЮУрГУ ММП). 2019. Т. 12, № 1. С. 5-19 
for applying in modelling the ECM process of the Faraday's law

$$
V_{\text {ecm }}=k \eta \frac{j}{\kappa}, \quad k=\kappa \varepsilon / \rho
$$

where $V_{e c m}$ is the rate of electrochemical dissolution, $\varepsilon$ is an electrochemical equivalent, $\rho$ is a density of dissolved metal, $\kappa$ is an electrolyte conductivity, $j_{1}$ is the critical value of current density, restricted the dissolution region.

If we use models (1), (2), the quasi-stationary approximation is formed by specifying the usual stationary condition on the parts with a high current density and condition $j=j_{1}$ on other parts [23]. The dissolution is absent in areas where $j<j_{1}$ and the original shape of the workpiece is retained. The approximation is to use the stationarity condition, since in reality the stationary solution is established asymptotically. Condition $j=j_{1}$ in non-stationary processes fulfills dynamically when the current efficiency changes abruptly from zero to $\eta_{0}$ and conversely, therefore does not lead to inaccuracy.

In this work we apply to a quasi-stationary model of electrochemical vertical cutting by a plate electrode-tool. The stationary problem of this type is solved in [14]. The electric field, as in [14], is considered to be potential and solenoidal. Therefore, the methods of the theory of functions of complex variables $[24,25]$ are used to solve the problems.

\section{The Quasi-Stationary Problem}

Let us consider the shaping problem of machining surface on machining by the plane semi-infinite vertical electrode-tool (ET) $A^{\prime} C B^{\prime}$ that moves vertically downwards with constant velocity $V_{e t}$. The cut of inter-electrode space (IES) is shown in Fig. 1 a. Let $U$ is potential difference between the equipotential anode and cathode. Then a band with width $U$ (Fig. $1 \mathrm{~b}$ ) is the image of IES on complex potential plane $W=\Phi+i \Psi$ ( $\Phi$ is electric field potential, $\Psi$ is the stream function).

The time variation is binding in the given problem statement with edge shift of ET $C$ in the direction of the machining surface. It means that $L=V_{e t} t$ is the deepening of ET downwards under the initial surface.

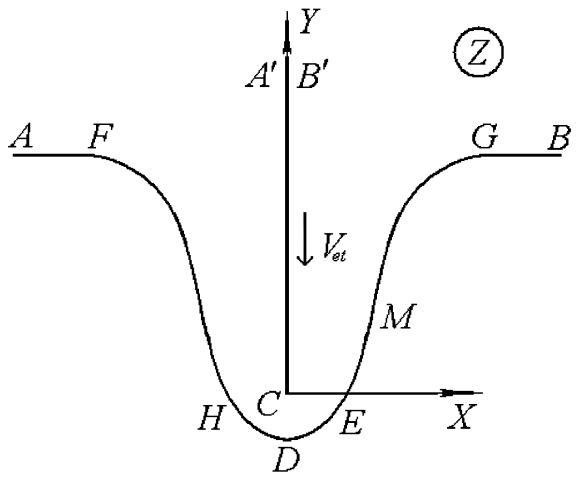

a

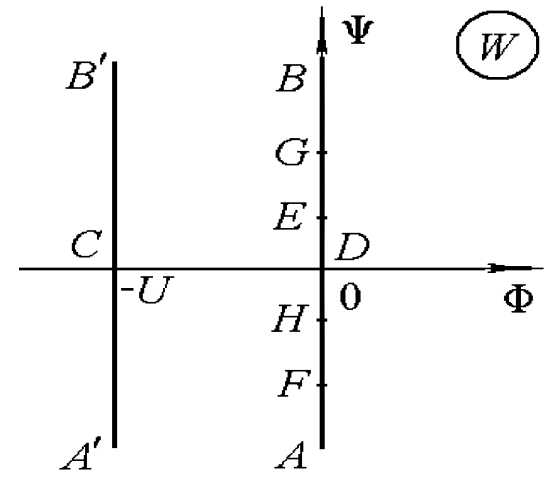

$\mathrm{b}$

Fig. 1. The cut of inter-electrode space: $a$ - the physical plane; $b$ - the complex potential plane. $H D E$ is the active dissolution area; $E M G, F H$ are the areas of constant (critical) value of strength; $A F, G B$ are the insoluble (rectilinear) boundaries 
The dependence of current efficiency on strength is simulated by stepwise function (1). In this case the tree domains with tree types of boundary conditions are formed on machining surface [22].

Dissolution is absent on horizontal parts $A F$ and $G B$, where $|E|<E_{1}$. Vertical line segment $G B$ corresponds to it on strength hodograph plane $\bar{E}=d W / d Z$ (Fig. 2 a), as far as the strength vector is directed along the normal to the equipotential surfaces from the cathode to the anode. By symmetry, the right half of plane domain $\bar{E}$ is considered.

Part $H D E$ is characterized by the stationarity condition. The strength is greater than $E_{1}$ because of proximity to ET. As in the stationary problem on the plane of strength hodograph circle arc [14] with radius $E_{0} / 2$ and center at point $i E_{0} / 2$ (where $E_{0}=V_{e t} /\left(k \eta_{0}\right)$ is the strength at point $D$ ) corresponds to section (Fig. 2 a).

A circle arc with radius $E_{1} \leq E_{0}$ and center at the origin of coordinates corresponds to transitional section $|\bar{E}|=E_{1} E M G$ ( $M$ is boundary inflection point). The existence of the area of a constant strength equal to the critical value is the main condition of quasi-stationary model construction.

Note, border part $E G$ can have a cut on plane $\bar{E}$ as far as this boundary is not stationary in contrast to problem [14]. But border part $D E$ cannot have a cut on plane $\bar{E}$ because there is no dissolution and the stationarity condition is violated if $|\bar{E}|<E_{1}$. So, the absence of cut on $D E$ is the condition of the quasi-stationary solution existence.
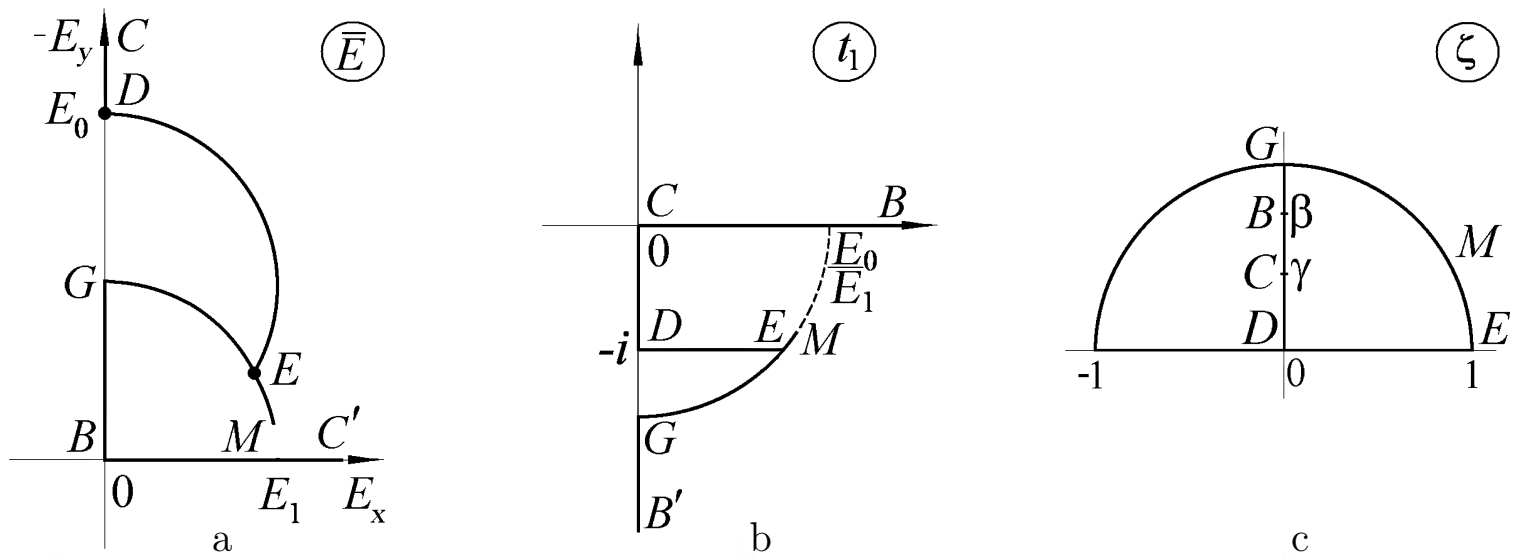

Fig. 2. The cut of inter-electrode space: a - the strength hodograph plane; b,c - the parametric planes

Thus, the problem is reduced to finding a conformal mapping of the region of $W$-plane to the domain of plane $\bar{E}$. Since the forms on both domains are known, then, in case of known correspondence to three points on the boundaries of these domains (in given problems $B, C, D)$, according to Riemann's theorem on conformal mapping [24, 25], the solution of this problem exists and it is unique. The length of cut $E M$ determines the depth of embedment $L$ of edge ET $C$ in the workpiece.

The problem is solved in a parametric form. Let us introduce parametric planes $t_{1}=$ $E_{0} / \bar{E}$ and $\zeta$, which domains are shown in Fig. 2 b, c. Conformal mapping $t_{1}(\zeta)$ is more convenient to find with the help of numerical integration of the derivative

$$
\frac{d t_{1}}{d \zeta}=\frac{1}{\left(\zeta^{2}+\gamma^{2}\right)^{1 / 2}\left(\zeta^{2}+\beta^{2}\right)^{3 / 2}} \mu(\zeta),
$$


as far as the derivative has real values on boundary parts $D E, D C, B G$ and imaginary values on part $B C$. In this case, first factor (3) takes into account the power singularities of the derivative. Second factor $(3) \mu(\zeta)$ must have purely real values on horizontal and vertical radiuses $\zeta$. Thus, according to the principle of symmetry, the function can be analytically continued to the whole circle and can be represented as the Taylor series converging inside circle [24]

$$
\mu(\zeta)=\sum_{m=0}^{\infty} c_{2 m} \zeta^{2 m}
$$

Upper half-plane $t_{2}=-0,5\left(\zeta^{2}+\zeta^{-2}\right)$ is used for obtaining of mapping $W(\zeta)$ (Fig. 3).

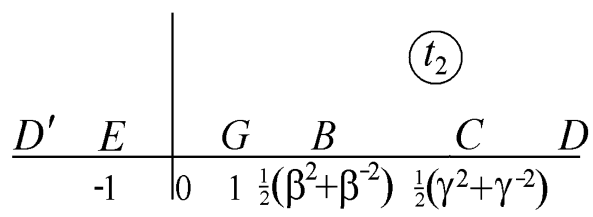

Fig. 3. The domain shape on parametric plane $t_{2}$

Function $W\left(t_{2}\right)$ is defined with help of Schwartz-Christoffel transformation [24]

$$
W\left(t_{2}\right)=-i \frac{U}{\pi} \ln \frac{\sqrt{t_{2}-\frac{1}{2}\left(\gamma^{2}+\gamma^{-2}\right)}-\sqrt{\frac{1}{2}\left(\beta^{2}+\beta^{-2}\right)-\frac{1}{2}\left(\gamma^{2}+\gamma^{-2}\right)}}{\sqrt{t_{2}-\frac{1}{2}\left(\gamma^{2}+\gamma^{-2}\right)}+\sqrt{\frac{1}{2}\left(\beta^{2}+\beta^{-2}\right)-\frac{1}{2}\left(\gamma^{2}+\gamma^{-2}\right)}} .
$$

Function $Z(\zeta)$ is obtained by integration

$$
Z(\zeta)=\frac{1}{E_{0}} \int_{i \gamma}^{\zeta} t_{1}(\zeta) \frac{d W}{d \zeta} d \zeta=\frac{1}{E_{0}} W(\zeta) \int_{i \gamma}^{\zeta} \frac{d t_{1}}{d \zeta} d \zeta-\frac{1}{E_{0}} \int_{i \gamma}^{\zeta} W(\zeta) \frac{d t_{1}}{d \zeta} d \zeta
$$

The calculation of machining surface shape is realized by numerical integration (5) by the method of parabolas. Function $t_{1}(\zeta)$ is computed by numerical integration (3) with condition $t_{1}(0)=-i$.

The problem is solved by collocation method, $n+1$ summands preserved in sum (3). Coefficients $c_{2 m}, m=0, \ldots, n$, and also parameters $\beta, \gamma$ are determined from condition $\left|t_{1}\left(e^{i \sigma}\right)\right|=\alpha=E_{0} / E_{1}$ given in discrete set of knots $\sigma_{m}=m \pi /(2 n), m=1, \ldots, n$. In addition, condition of closure $\operatorname{Re} t_{1}(i)=0$ and the geometric conditions $\operatorname{Im} t_{1}(\gamma)=0$, $\operatorname{Im} Z(i)=L$ must be satisfied. Resulting system of $n+3$ nonlinear equations is solved by the Newton method with step control by minimizing of the residuals squares sum.

Let us denote typical dimension as $S=U / E_{0}=k \eta_{0} U / V_{e t}$, parameter $\alpha=E_{0} / E_{1}$, $\alpha \geq 1$

$$
z=\frac{Z}{S}, \quad \tau=\frac{V_{e t}}{S} t
$$

( $t$ is the time, $\tau$ is dimensionless time). As far as $L=V_{e t} t$, then $\tau=L / S$.

The numerical results for $\alpha=2$ and $\tau=3 ; 4 ; 5 ; \ldots$ are given in Fig. 4 a in comparison with stationary solution (curve 1) obtained in [14]. The shapes are shown at coordinates 

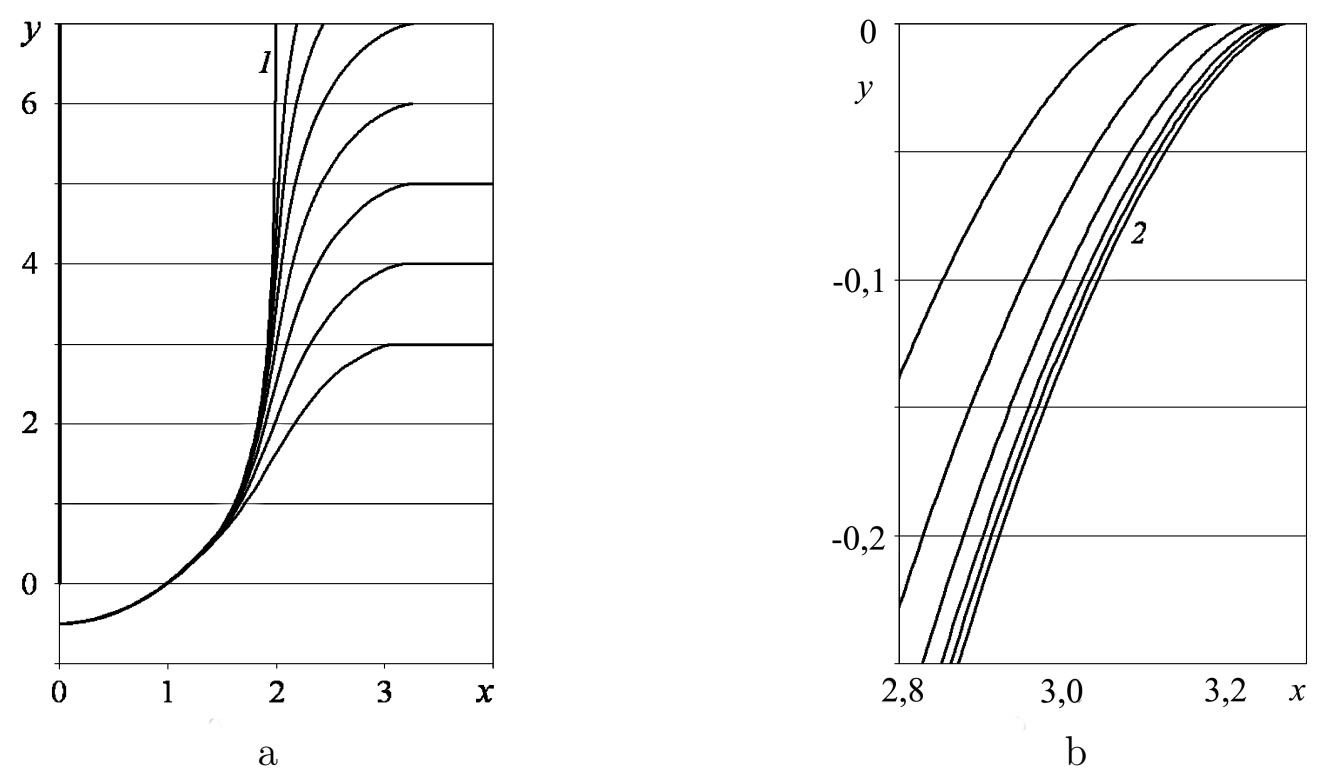

Fig. 4. Computations results for $\alpha=2$ : $\mathrm{a}$ - the machining surface shapes; $\mathrm{b}$ - the part of the surface close to insoluble area

system connected with moved ET. It allows visualization of the limit shape establishment near ET border.

This solution is compared with the limit solution appearing nearby insoluble part of surface $(G B)$ at fixed coordinates system in Fig. 4 b. Known problem [26] of flow from under a linear shield (curve 2 ) is this limit solution

$$
z=\frac{2}{\pi}\left(-\frac{2}{e^{\pi w / 2}+\sqrt{e^{\pi w}+1}-1}+\ln \left(e^{\pi w / 2}+\sqrt{e^{\pi w}+1}\right)\right)-\frac{2}{\pi}, \quad z=\frac{Z}{S}, \quad w=\frac{W}{U} .
$$

Filtration method [27] of numerical data series obtained for $\tau_{j}=3 ; 4 ; 5 ; 6 ; 7 ; 8 ; 9$ is applied for estimation of the limit parameters values for $\tau \rightarrow \infty$. Front gap $s_{f}$ and abscissa of point $G$ (in which the ordinate of quasi-stationary surface is equal to zero) are used as characteristic parameters. A priori model of the process is used and tested

$$
s_{j}=s_{\infty}+c_{1} e^{-p_{1} \tau_{j}}+c_{2} e^{-p_{2} \tau_{j}}+\ldots+c_{J} e^{-p_{J} \tau_{j}}+\Delta\left(\tau_{j}\right) .
$$

Here $s_{j}$ are the calculated gap values; $s_{\infty}$ is the required magnitude of the steady gap; $c_{k}$ and $p_{k}$ are unknown coefficients; $\Delta\left(\tau_{j}\right)$ is an error that consists of not included terms of the expansion in the sum, the rounding error and other components due to the features of the algorithm and software. Filtration [27] consists in the repeated application of the formulas of Aitken [28] and Richardson [29]

$$
e^{p_{1}} \approx \frac{s_{j-2}-s_{j-1}}{s_{j-1}-s_{j}}, \quad s_{j}^{(1)}=s_{j}+\frac{s_{j}-s_{j-1}}{e^{p_{1}}-1} .
$$

After applying of transformation (9) to all values $s_{j}$, new sequence $s_{j}^{(1)}$ is obtained, the model of which is similar to (8), but does not contain term $c_{1} e^{-p_{1} \tau_{j}}$. Then transformation (9) can be applied again to eliminate term $c_{2} e^{-p_{2} \tau_{j}}$, and so on.

The filtration process is controlled by the results visualization. Relative errors are estimated by the way of comparison with a single standard which is elected as one of 
values obtained by filtration. To verify the correctness of the standard choice, a sequence of differences $s_{j}^{(k)}-s_{j+1}^{(k)}$ is constructed, which does not contain $s_{\infty}$. For this sequence the standard is zero, and its filtration is performed according to the specified rules. In the case of the correct choice of the standard the lines on the graph, corresponding to the comparison with the standard are superimposed on the lines obtained by pairwise subtraction.

The decimal logarithms (with negative sign) of relative error estimates $\delta$ are put on the ordinate axis in Fig. 5. It shows the number of valid digits of a result and allows estimating the error decrease rate. The values of dimensionless time $\tau$ are put on the abscissa axis. The results of filtration of data differences that correspond to the sequential values $\tau$ are shown in Fig. 5 a as the bold lines. It facilitates the standard choice with which all computed and filtered values are compared. Line 0 corresponds to the differences of computed values; lines 1 and 2 correspond to the filtered values. The results of standard choice for $s_{f}=0,4982668$ and comparison of computed and filtered values with it are presented in Fig. 5 a as thin lines put onto bold ones. The value of order $3 \cdot 10^{-7}$ is obtained as the result of error estimation of the standard. An additional verification of the error estimate obtained is carried out by comparison with the value of stationary gap $s_{f}=0,49826686$, obtained in [14] with greater accuracy. The comparison shows, that the determined difference is less than $10^{-7}$, and it confirms the estimate.

The filtration of expression

$$
p_{1} \approx-\frac{1}{\Delta_{\tau}} \ln \frac{s_{f}\left(\tau+\Delta_{\tau}\right)-s_{\infty}}{s_{f}(\tau)-s_{\infty}}
$$

is fulfilled for definition of coefficient $p_{1}$ and value $p_{1}=0,7882 \pm 10^{-4}$ is obtained (Fig. $5 \mathrm{~b}$ ).

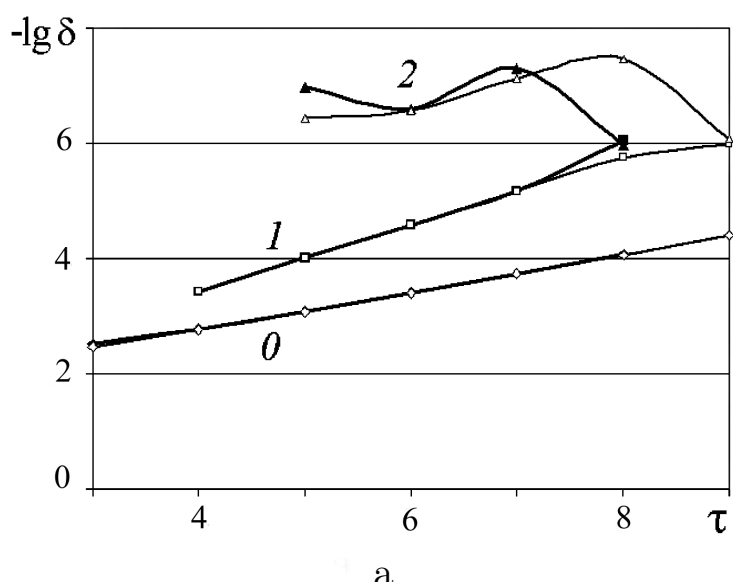

a

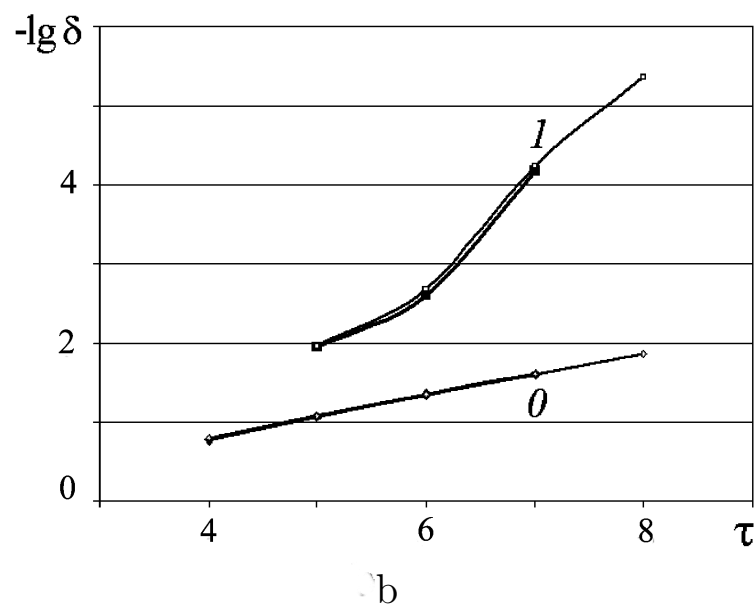

$\mathrm{b}$

Fig. 5. The filtration results of numerical data sequence (lateral gap): a - the estimate of the limiting value $s_{\infty} ; \mathrm{b}$ - coefficient $p_{1}$ estimate

The similar estimates for abscissa $x_{G}$ of point $G$ is obtained $x_{G}=3,273244 \pm 10^{-5}$. As far as the accurate limiting value of parameter $\alpha(\pi+2) / \pi$ is known from solution of the problem of flow from under a linear shield (7), we can find the accurate error value $5 \cdot 10^{-6}$. It isn't contradicting the estimate obtained without accurate value application. As for $s_{f}(\tau)$ coefficient $q_{1}$ of exponential $x_{G}$ dependence as (8) $c_{1} e^{-q_{1} \tau}$ is determined $q_{1}=0,7923 \pm 10^{-4}$.

The particular case is $\alpha=1\left(E_{0}=E_{1}\right)$, when circle arc EMG takes up arc DE on plane $\bar{E}$ (Fig. 2 a). The analytical solution of this problem is obtained in [23]. The asymptotical 
expression particularly follows from this solution

$$
s_{f} \approx \frac{2}{\pi} \ln 2+\frac{2(1-\ln 2)}{\pi e} e^{-\pi \tau / 2}, \quad x_{G} \approx \frac{1}{\pi}\left[2+\pi-\left(2+\frac{\pi}{2}\right) e^{-\pi \tau / 2}\right] .
$$

\section{The Comparison with Non-Stationary Solution}

The non-stationary problem is solved by the method described in $[17,18]$. It is defined the conformal mapping of band $\chi=-i W /(2 U)$ (parametric variable) onto physical plane $z=Z / S$ and also partial derivative $\partial z / \partial \tau(\chi, \tau)$ of dimensionless coordinates with respect to dimensionless time (6) for determination the boundary shift on each step of algorithm. The dimensionless velocity of ET is equal to 1 for the given way of dimensionlessness (6).

The partial derivative is determined from solution of the equation as Polubarinova Galin [30], which follows from Faraday law (2)

$$
\operatorname{Im}\left(\overline{\frac{\partial z}{\partial \sigma}} \frac{\partial z}{\partial \tau}\right)=-\eta\left(\left|\frac{d w}{d z}\right|\right) \operatorname{Im} \frac{\partial w}{\partial \sigma},
$$

where $\sigma=\operatorname{Re\chi }, w=W / U, \partial w / \partial \sigma=2 i$.

The application of the stepwise function (1) leads to dissolution switch on or off under passage of strength modulo value through the critical value $E_{1}$. It is realized with multiplication of the right part of (10) by 1 or 0 .

The function conformally mapping a band of parametric variable plane $\chi$ on IES area of the physical plane at the fixed relative to the workpiece body coordinate system is defined as sum

$$
z(\chi, \tau)=g(\tau) \sinh \pi \chi+z_{\Delta}(\chi, \tau)
$$

where function $z_{0}(\chi)=g \sinh \pi \chi$ for $g>0$ conformally maps the band of plane $\chi$ on the upper half-plane with a cut; $z_{\Delta}(\chi, \tau)$ is an analytical function which determines the distinctions of the machining surface form from the linear one (in this case $\operatorname{Im} z(\infty, \tau)=0$ ).

The ordinate of point ET is defined from the equation

$$
z\left(\frac{i}{2}, \tau\right)=g(\tau)+z_{\Delta}\left(\frac{i}{2}, \tau\right)=s_{0}-\tau
$$

( $s_{0}$ is the dimensionless initial gap value). Then the derivative

$$
\frac{d g}{d \tau}=-1-\frac{\partial}{\partial \tau} z_{\Delta}\left(\frac{i}{2}, \tau\right) .
$$

We introduce the grid for parameters $\sigma$ and $\tau$ :

$$
\sigma_{m}=m \Delta_{\sigma}, \quad m=0,1, \ldots, n ; \quad \tau_{j}=j \Delta_{\tau}, \quad j=0,1, \ldots, M .
$$

So, values $\frac{\partial z_{\Delta}}{\partial \tau}\left(\sigma_{m}, \tau_{j}\right)$ are determined on every time step for known $z_{\Delta}\left(\sigma_{m}, \tau_{j}\right)$ and $\frac{\partial z_{\Delta}}{\partial \sigma}\left(\sigma_{m}, \tau_{j}\right)$ with the help of solving of linear equations system, which are obtained by substitution $\sigma_{j}$ in (10). And $z_{\Delta}$ is varied by the Euler method

$$
z_{\Delta}\left(\sigma_{m}, \tau_{j+1}\right)=z_{\Delta}\left(\sigma_{m}, \tau_{j}\right)+\frac{\partial z_{\Delta}}{\partial \tau}\left(\sigma_{m}, \tau_{j}\right) \Delta_{\tau}
$$


Then $\frac{\partial z_{\Delta}}{\partial \tau}\left(\sigma_{m}, \tau_{j}\right)$ are calculated once more and so on.

Thus, it is necessary to find two analytical functions of a complex variable on every time step

$$
f_{1}\left(z, \tau_{j}\right)=z_{\Delta}\left(z, \tau_{j}\right), \quad f_{2}\left(z, \tau_{j}\right)=\frac{\partial z_{\Delta}}{\partial \tau}\left(z, \tau_{j}\right) .
$$

Functions $f_{1}\left(z, \tau_{j}\right)$ and $f_{2}\left(z, \tau_{j}\right)$ are found as follows. We find the solution at mesh points $\sigma_{m}(m=0, \ldots, n)$ on boundary $\chi=\sigma$. Values $\operatorname{Im} f_{k}\left(\sigma_{m}, \tau_{j}\right)=f_{m}^{k}(k=1,2)$ are given. We assume $\operatorname{Im} f_{k}\left(\sigma_{n}, \tau_{j}\right)=0$, as far as $\operatorname{Im} f_{k}\left(\sigma, \tau_{j}\right)$ decreases fast (as an exponent) for $\sigma \rightarrow \pm \infty$. Values $\operatorname{Im} f_{k}\left(\sigma, \tau_{j}\right)$ at points between mesh points are found with help of cubic splines $S_{k}\left(\sigma, \tau_{j}\right)$ having two continuous derivatives.

As far as $f_{k}\left(\chi, \tau_{j}\right)$ are analytical functions with pure imaginary values on straight line $\operatorname{Im} \chi=1 / 2$, we continue these functions up to a band of unit width. Then $\operatorname{Im} f_{k}\left(\sigma+i, \tau_{j}\right)=$ $\operatorname{Im} f_{k}\left(\sigma+i 0, \tau_{j}\right)$ by virtue of symmetry principle [24]. The Schwarz formula is applied for reconstruction of functions $f_{k}\left(\chi, \tau_{j}\right)(k=1,2)$, taking into account that $\operatorname{Im} f_{k}\left(\sigma, \tau_{j}\right)$ due to symmetry are the even functions with respect to $\sigma[17,18]$

$$
f_{k}(\chi, \tau)=\sinh \pi \chi \int_{0}^{\infty} \frac{S_{k}\left(\sigma, \tau_{j}\right) d \sigma}{\cosh \pi \sigma-\cosh \pi \chi}+\sinh \pi \chi \int_{0}^{\infty} \frac{S_{k}\left(\sigma, \tau_{j}\right) d \sigma}{\cosh \pi \sigma+\cosh \pi \chi}
$$

Derivative values $\operatorname{Im} \frac{\partial z_{\Delta}}{\partial \sigma}\left(\sigma_{m}, \tau_{j}\right)$ are equal to the coefficients of spline $S_{1}\left(\sigma, \tau_{j}\right)$ constructed according to mesh values $f_{m}^{1}=\operatorname{Im} z_{\Delta}\left(\sigma_{m}, \tau_{j}\right)$, and derivative $\operatorname{Re} \frac{\partial z_{\Delta}}{\partial \sigma}\left(\sigma_{m}, \tau_{j}\right)$ is defined by computation of the coefficients of the spline constructed according to mesh values $x_{m}=\operatorname{Re} f_{1}\left(\sigma_{m}, \tau_{j}\right)$ obtained from (12).

The shapes of non-stationary surface in fixed coordinates system is shown in Fig. 6 a. The step of dimensionless time $\Delta \tau$ is equal to 1 . The dimensionless rate of $\mathrm{ET}$ is equal to 1. The images of these curves on the strength hodograph plane $(\Delta \tau=0,5)$ are presented in Fig. 6 b. One can see the formation of quasi-stationary mode (see Fig. 2 a).
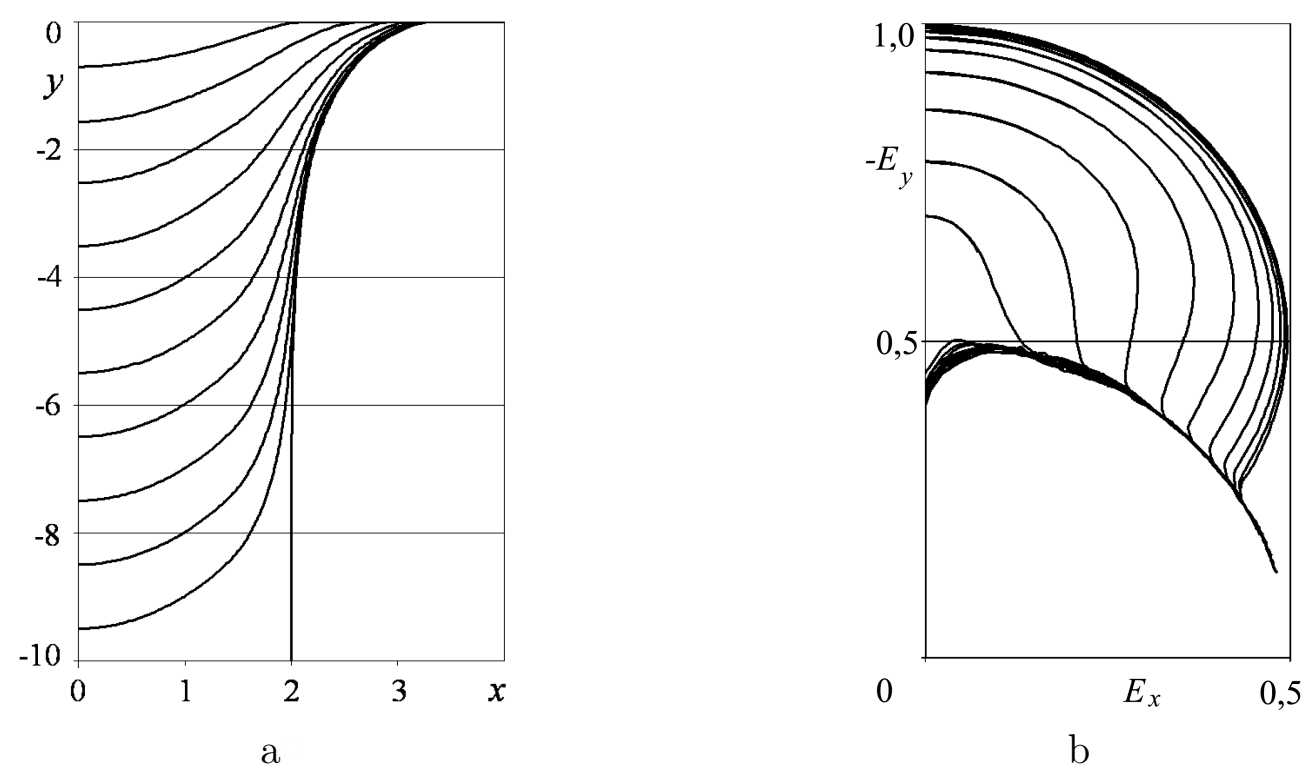

Fig. 6. Computations results: a - machining surface shapes $(\Delta \tau=1) ; \mathrm{b}$ - machining surface images on the strength hodograph plane $(\Delta \tau=0,5)$ 


\section{On Error Estimation}

It is detected that shape error in non-stationary problem solving is the highest near the dissolution absent area. The surface shapes neighborhood point $G$ in comparison with the solution of problem of fluid flow from under a shield (curve 1) are shown in Fig. 7. One can see that absolute error exceed 0,1 for nodes number $n=144$ and it decreases to 0,02 approximately (the relative error is smaller by order) for $n=729$.
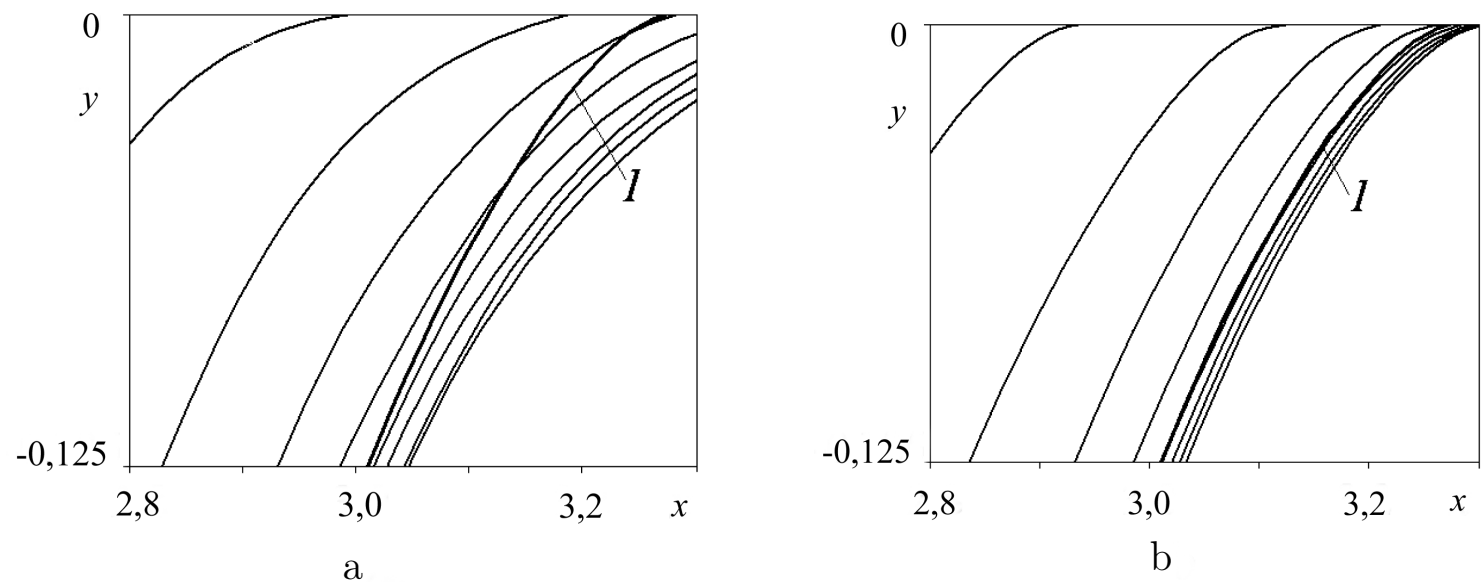

Fig. 7. The surface part near the insoluble area: $\mathrm{a}-n=144 ; \mathrm{b}-n=729$

The solution of differential equation (10) with the discontinuous right part leads to questions appearance about method accuracy order. The numerical filtration of results obtained for different $\Delta \tau$ and $n$, described in [27], is applied for error estimation.

The error investigation with the filtration application of the numerical data, obtained for $L=5, n=144,216,324,486,729$ and $\Delta \tau=(1,0,5,0,25,0,125,0,0625,0,03125)$. $10^{-3}$ is realized. The ordinate of non-stationary surface at point $G$ (at which the ordinate of quasi-stationary surface is equal to zero) is used as a magnitude characterizing the error. The filtration results of numerical data obtained for different $\Delta \tau$ for $n=729$ are shown in Fig. 7 a. The decimal logarithms of relative error with negative sign are put on the ordinate axis. The decimal logarithms of relation of the dimensionless time step $\Delta \tau$ to $\Delta \tau_{0}=0,01$ are put on the abscissa axis. The filtration results of subtraction of the data corresponding to the sequential values $\Delta \tau$ are shown by bold lines. The choice results of the standard that equal to $1,6 \cdot 10^{-3}$ and comparison results of the computed and filtered data with the standard are presented in Fig. 8 a by thin lines.

The numerical data filtration results obtained for different $n$ and previously filtered with respect to $\Delta \tau$ are demonstrated in Fig. 8 b. The bold lines show the filtration results of data subtractions corresponding to the sequential values $n$ for the standard choice. The curve 0 corresponds to the subtraction of the computed values, curves 1 and 2 correspond to the values filtered one and two times. The thin lines show the choice results of the standard equal to $\Delta_{0}=-0,5 \cdot 10^{-3}$ and comparison results of the computed and filtered data with the standard. Note, that the line 1 is used for error estimation. The line 2 is used for this estimate approval only. One can see that the certain accuracy estimate shows hardly more than 3 digits. It makes to consider this result $\Delta_{0}$ doubtful. Thus, it has not succeeded to find a difference between non-stationary and quasi-stationary solutions exceeding the computational error. 

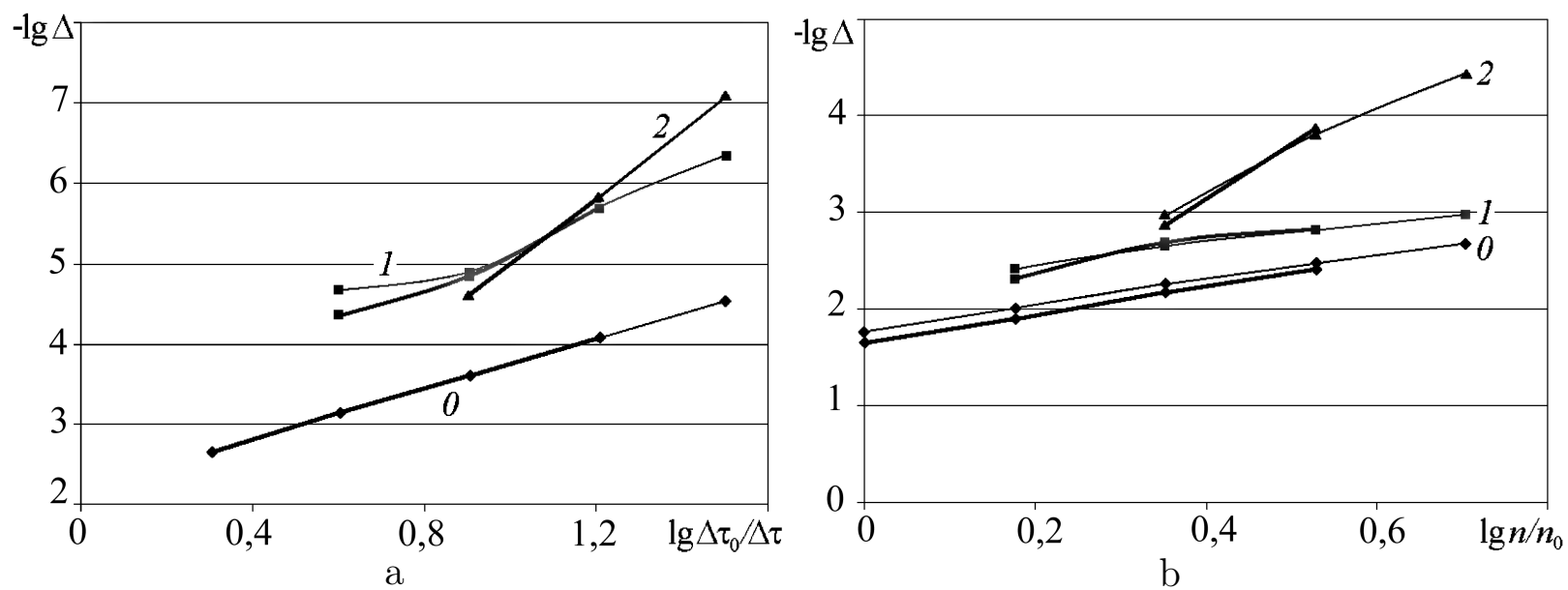

Fig. 8. Filtration results: $\mathrm{a}-$ for $\Delta \tau ; \mathrm{b}-$ for $n$

\section{Conclusion}

The problem of quasi-stationary ECM is formulated and solved in this paper. The application of the stepwise function of current efficiency on current density has leaded to the appearance on the machining surface the segments with the three types of boundary conditions (stationary, transient and insoluble). It allows explanation of real process nature by comparison of the machining surface shape on the transient segments and the shape of free surface in hydrodynamic problem about flow from under a linear shield (particularly, by infinite curvature of the surface at the separation point).

The numerical investigations results allow obtaining the characteristics of nonstationary processes of formation. It is found that variation of characteristic sizes (for example: front gap) of non-stationary solution corresponds to the exponential low. There are found concrete dependences of these parameters on time. They are important for technologies development of precision electrochemical machining.

The obtained results allow to compare non-stationary problems solutions with stationary and quasi-stationary solutions. It simplifies error estimating and increases numerical results reliability. And also the diapasons of simplified methods applicability of investigation of non-stationary processes (quasi-stationary and limiting-quasi-stationary) are found.

The condition of quasi-stationary process formation is monotonously-increasing of the strength at the machining surface points. For example, it is correct for machining by a vertical plane and angular ET and it is not correct for machining by point ET and horizontal plane ET (for a long time). In these two cases and other similar ones the final mode forms on the machining surface part bordering on insoluble zone. The dissolution is absent and the form remains invariable for this region.

The numerical investigations show that in the case of quasi-stationary process the limiting area of machining surface forms rather quickly. This area is restricted by the condition of the strength modul equality to the critical value. The stationary area forms more slowly therefore a quasi-stationary solution is possible for $\tau \geq \tau_{0}$, where $\tau_{0}=\tau_{0}(\alpha)$.

The comparison of the obtained non-stationary and quasi-stationary shapes (in the existence range of consistent solutions of quasi-stationary problems) shows the absence of differences exceeding error of non-stationary problem solution (about $10^{-3}$ ). 
Acknowledgements. This work was financially supported by the Russian Foundation for Basic Research (Project no. 17-07-00356).

\section{References}

1. Klokov V.V. Influence of Alternating Current Output on Stationary Anode Shaping. Workshop of the Seminar on Boundary Value Problems. Kazan, Kazan State University, 1979, vol. 16, pp. 94-102. (in Russian)

2. Gazizov E.R., Maklakov D.V. A Method for Calculating Anodic Shaping by a Dihedral Cathode for an Arbitrary Current-Output Dependence. Teorija $i$ praktika elektrofizikokhimicheskikh metodov obrabotki detaley $v$ aviastrojenii [Theory and Practice of Electrophysico-Chemical Methods of Processing Details in Aircraft Building], Kazan, Kazan Aviation Institute, 1994, pp. 32-35. (in Russian)

3. Datta M., Landolt D. Fundamental Aspects and Applications of Electrochemical Microfabrication. Electrochimica Acta, 2000, vol. 45, pp. 2535-2558. DOI: 10.1016/S00134686(00)00350-9

4. Forster R., Schoth A., Menz W. Micro-ECM for Production of Microsystems with a High Aspect Ratio. Microsystem Technologies, 2005, vol. 11, pp. 246-249. DOI: 10.1007/s00542004-0374-7

5. Shin H.Sh., Kim B.H., Chu Ch.N. Analysis of the Side Gap Resulting from Micro Electrochemical Machining with a Tungsten Wire and Ultrashort Voltage Pulses. Journal of Micromechanics and Microengineering, 2008, vol. 18, pp. 1-6. DOI: 10.1088/0960$1317 / 18 / 7 / 075009$

6. Wang S., Zhu D., Zeng Y., Liu Y. Micro Wire Electrode Electrochemical Cutting with Low Frequency and Small Amplitude Tool Vibration. International Journal of Advanced Manufacturing Technology, 2011, vol. 53, no. 5-8, pp. 535-544. DOI: 10.1007/s00170-0102835-8

7. Wang F.Y., Xu J.W., Zhao J.S. Numerical Simulation of Electrochemical Machining Process and Machined Surface Prediction. Key Engineering Materials, 2011, vol. 45, no. 8, pp. 99-105. DOI: 10.4028/www.scientific.net/KEM.458.99

8. Qu N., Fang X., Li W., Zeng Y., Zhu D. Wire Electrochemical Machining with Axial Electrolyte Flushing for Titanium Alloy. Chinese Journal of Aeronautics, 2013, vol. 26, no. 1, pp. 224-229. DOI: 10.1016/j.cja.2012.12.026

9. Zhu D., Liu C., Xu Z., Liu J. Cathode Design Investigation Based on Iterative Correction of Predicted Profile Errors in Electrochemical Machining of Compressor Blades. Chinese Journal of Aeronautics, 2016, vol. 29, no. 4, pp. 1111-1118. DOI: 10.1016/j.cja.2016.01.003

10. Kotlyar L.M., Minazetdinov N.M. Modelling of Electrochemical Machining with the Use Of a Curvilinear Electrode and a Stepwise Dependence of the Current Efficiency on the Current Density. Journal of Applied Mechanics and Technical Physics, 2016, vol. 57, no. 1, pp. 127-135. DOI: 10.1134/S0021894416010144

11. Guo C., Qian J., Reynaers D. Electrochemical Machining with Scanning Micro Electrochemical Flow Cell. Journal of Materials Processing Technology, 2017, vol. 24, no. 7, pp. 171-183. DOI: 10.1016/j.jmatprotec.2017.04.017

12. Volgin V.M., Davydov A.D. Pseudotransient Method for Modelling of Electrochemical Machining. Russian Journal of Electrochemistry, 2017, vol. 53, no. 10, pp. 1109-1121. DOI: $10.1134 / \mathrm{S} 1023193517100147$

13. Guo C., Qian J., Reynaers D. A Three-Dimensional FEM Model of Channel Machining by Scanning Micro Electrochemical Flow Cell and Jet Electrochemical Machining. Precision Engineering, 2018, vol. 52, pp. 507-519. DOI: 10.1016/j.precisioneng.2018.02.002 
14. Zhitnikov V.P., Sherykhalina N.M., Porechny S.S. Stationary Electrochemical Machining Simulation Applying to Precision Technologies. Bulletin of the South Ural State University. Series: Mathematical Modelling, Programming and Computer Software, 2017, vol. 10, no. 4, pp. 15-25. DOI: $10.14529 / \mathrm{mmp} 170402$

15. Christiansen S., Rasmussen H. Numerical Solutions for Two-Dimensional Annular Electrochemical Machining Problems. Journal of the Institute of Mathematics and Its Applications, 1976, no. 18, pp. 295-307. DOI: 10.1093/imamat/18.3.295

16. Kenney J.A., Hwang G.S. Electrochemical Machining with Ultrashort Voltage Pulses: Modelling of Charging Dynamics and Feature Profile Evolution. Nanotechnology, 2005, vol. 16, no. 7, pp. 309-313. DOI: 10.1088/0957-4484/16/7/001

17. Zhitnikov V.P., Fedorova G.I., Zinatullina O.V., Kamashev A.V. Simulation of NonStationary Processes of Electrochemical Machining. Journal of Materials Processing Technology, 2004, vol. 149, no. 1-3, pp. 398-403. DOI: 10.1016/j.jmatprotec.2004.02.014

18. Zhitnikov V.P., Fedorova G.I., Sherykhalina N.M., Urakov A.R. Numerical Investigation of Non-Stationary Electrochemical Shaping Based on an Analytical Solution of the HeleShaw Problem. Journal of Engineering Mathematics, 2006, vol. 55, no. 1-4, pp. 255-276. DOI: $10.1007 / \mathrm{s} 10665-005-9018-\mathrm{x}$

19. Volgin V.M., Do V.D., Davydov A.D. Modelling of Wire Electrochemical Machining. Chemical Engineering Transactions, 2014, vol. 41, pp. 91-96. DOI: 10.3303/CET1441016

20. Volgin V.M., Lyubimov V.V., Gnidina I.V., Davydov A.D., Kabanova T.B. Effect of Current Efficiency on Electrochemical Micromachining by Moving Electrode. Procedia CIRP, 2016, vol. 55, pp. 65-70. DOI: $10.1016 /$ j.procir.2016.08.031

21. Chen Y., Fang M., Jiang L. Multiphysics Simulation of the Material Removal Process in Pulse Electrochemical Machining (PECM). International Journal of Advanced Manufacturing Technology, 2017, vol. 91, no. 5-8, pp. 2455-2465. DOI: 10.1007/s00170-016-9899-z

22. Zhitnikov V.P., Oshmarina E.M., Fedorova G.I. The Use of Discontinuous Functions for Modelling the Dissolution Process of Steady-State Electrochemical Shaping. Russian Mathematics, 2010, vol. 54, no. 10, pp. 67-70. DOI: 10.3103/S1066369X10100099

23. Zhitnikov V.P., Oshmarina E.M., Fedorova G.I. Exact Solutions of Two Limiting Quasistationary Electrochemical Shaping Problems. Russian Mathematics, 2011, vol. 55, no. 12 , pp. 16-22. DOI: 10.3103/S1066369X11120036

24. Lavrentjev M.A., Shabat B.V. Metody teorii funktsiy kompleksnogo peremennogo [Methods of the Theory of Functions of a Complex Variable]. Moscow, Nauka, 1987. (in Russian)

25. Henrici P. Applied and Computational Complex Analysis, N.Y., Wiley Classic Library, 1993.

26. Birkhoff G., Zarantonello E.H. Jets, Wakes and Cavities, N.Y., Academic Brennen, 1957.

27. Zhitnikov V.P., Sherykhalina N.M., Sokolova A.A. Problem of Reliability Justification of Computation Error Estimates. Mediterranean Journal of Social Sciences, 2015, vol. 6, no. 2, pp. 65-78. DOI: 10.5901/mjss.2015.v6n2s4p65

28. Aitken A.C. On Bernoulli's Numerical Solution of Algebraic Equations. Proceedings of the Royal Society of Edinburgh, 1926, vol. 46, pp. 289-305. DOI: 10.1017/S0370164600022070

29. Richargson L.F., Gaunt J.A. The Deferred Approach to the Limit. Philosophical Transactions of the Royal Society of London, 1927, vol. 226, pp. 299-361. DOI: 10.1098/rsta.1927.0008

30. Polubarinova-Kochina P.Ja. Theory of Groundwater Movement, Princeton, Princeton University Press, 1962.

Received April 15, 2018 


\title{
СРАВНЕНИЕ КВАЗИСТАЦИОНАРНОГО И НЕСТАЦИОНАРНОГО РЕШЕНИЙ ЗАДАЧ ЭЛЕКТРОХИМИЧЕСКОГО ФОРМООБРАЗОВАНИЯ ПРИМЕНИТЕЛЬНО К ПРЕЦИЗИОННОЙ РЕЗКЕ ПЛАСТИНЧАТЫМ ЭЛЕКТРОДОМ-ИНСТРУМЕНТОМ
}

\author{
В.П. Житников ${ }^{1}$, Н.М. Шерыхалина ${ }^{1}$, С.С. Поречны й \\ 1 Уфимский государственный авиационный технический университет, г. Уфа, \\ Российская Федерация
}

\begin{abstract}
Сформулирована квазистационарная задача для моделирования процесса электрохимической резки пластинчатым электродом-инструментом. Постановка задачи основана на использовании ступенчатой функции выхода по току от плотности тока. При этом на обрабатываемой поверхности образуются три зоны с различными условиями. В области высоких плотностей тока используется обычное условие стационарности. В области малых плотностей тока растворение отсутствует и сохраняется начальная форма границ. В промежуточной зоне плотность тока в каждой точке равна критическому значению. Наличие краевых условий на каждом участке обрабатываемой поверхности позволяет сформулировать краевую задачу для аналитической функции комплексного переменного и найти форму границы в любой момент времени, независимо от предыстории. Проведено сравнение решений квазистационарной и нестационарной задач, и найден диапазон существования квазистационарного решения.

Ключевые слова: электрохимическое формообразование; ступенчатая функиия; квазистационарная модель; оченка погрешности.
\end{abstract}

\section{Литература}

1. Клоков, В.В. Влияние переменного выхода по току на стационарное анодное формообразование / В.В. Клоков // Труды семинара по краевым задачам. - Казань: Казанский государственный университет. - 1979. - № 16. - С. 94-102.

2. Газизов, Е.Р. Метод расчета анодного формообразования двугранным катодом для произвольной зависимости выхода по току / Е.Р. Газизов, Д.В. Маклаков // Теория и практика электрофизикохимических методов обработки деталей в авиастроении. - Казань: Казанский авиационный институт. - 1994. - С. 32-35.

3. Datta, M. Fundamental Aspects and Applications of Electrochemical Microfabrication M. Datta, D. Landolt // Electrochimica Acta. - 2000. - V. 45. - P. 2535-2558.

4. Forster, R. Micro-ECM for Production of Microsystems with a High Aspect Ratio R. Forster, A. Schoth, W. Menz // Microsystem Technologies. - 2005. - V. 11. - P. 246-249.

5. Shin, H.Sh. Analysis of the Side Gap Resulting from Micro Electrochemical Machining with a Tungsten Wire and Ultrashort Voltage Pulses / H.Sh. Shin, B.H. Kim, Ch.N. Chu // Journal of Micromechanics and Microengineering. - 2008. - V. 18. - P. 1-6.

6. Wang, S. Micro Wire Electrode Electrochemical Cutting with Low Frequency and Small Amplitude Tool Vibration / S. Wang, D. Zhu, Y. Zeng, Y. Liu // International Journal of Advanced Manufacturing Technology. - 2011. - V. 53, № 5-8. - P. 535-544.

7. Wang, F.Y. Numerical Simulation of Electrochemical Machining Process and Machined Surface Prediction / F.Y. Wang, J.W. Xu, J.S. Zhao // Key Engineering Materials. - 2011. V. 45 , № 8. - P. 99-105. 
8. Qu, N. Wire Electrochemical Machining with Axial Electrolyte Flushing for Titanium Alloy / N. Qu, X. Fang, W. Li, Y. Zeng, Di Zhu // Chinese Journal of Aeronautics. - 2013. - V. 26, № 1. - P. 224-229.

9. Zhu, D. Cathode Design Investigation Based on Iterative Correction of Predicted Profile Errors in Electrochemical Machining Of Compressor Blades / D. Zhu, C. Liu, Z. Xu, J. Liu // Chinese Journal of Aeronautics. - 2016. - V. 29, № 4. - P. 1111-1118.

10. Котляр, Л.М. Моделирование электрохимического формообразования с использованием криволинейного электрода при ступенчатой зависимости выхода по току от его плотности / Л.М. Котляр, Н.М. Миназетдинов // Прикладная механика и теоретическая физика. - 2016. - Т. 44, № 1. - С. 146-155.

11. Guo, C. Electrochemical Machining with Scanning Micro Electrochemical Flow Cell / C. Guo, J. Qian, D. Reynaers // Journal of Materials Processing Technology. - 2017. - V. 24, № 7 . P. 171-183.

12. Волгин, В.М. Псевдонестационарный метод моделирования электрохимического формообразования / В.М. Волгин, А.Д. Давыдов // Электрохимия. - 2017. - Т. 53, № 10. C. $1248-1265$.

13. Guo, C. A Three-Dimensional FEM Model of Channel Machining by Scanning Micro Electrochemical Flow Cell and Jet Electrochemical Machining / C. Guo, J. Qian, D. Reynaers // Precision Engineering. - 2018. - V. 52. - P. 507-519.

14. Zhitnikov, V.P. Stationary Electrochemical Machining Simulation Applying to Precision Technologies / V.P. Zhitnikov, N.M. Sherykhalina, S.S. Porechny // Вестник ЮУрГУ. Серия: Математическое моделирование и программирование. - 2017. - Т. 10, № 4. P. $15-25$.

15. Christiansen, S. Numerical Solutions for Two-Dimensional Annular Electrochemical Machining Problems / S. Christiansen, H. Rasmussen // Journal of the Institute of Mathematics and its Applications. - 1976. - № 18. - P. 295-307.

16. Kenney, J.A. Electrochemical Machining with Ultrashort Voltage Pulses: Modelling of Charging Dynamics and Feature Profile Evolution / J.A. Kenney, G.S. Hwang // Nanotechnology. - 2005. - V. 16, № 7. - P. 309-313.

17. Zhitnikov, V.P. Simulation of Non-Stationary Processes of Electrochemical Machining / V.P. Zhitnikov, G.I. Fedorova, O.V. Zinatullina, A.V. Kamashev // Journal of Materials Processing Technology. - 2004. - V. 149, № 1-3. - P. 398-403.

18. Zhitnikov, V.P. Numerical Investigation of Non-Stationary Electrochemical Shaping Based on an Analytical Solution of the Hele-Shaw Problem / V.P. Zhitnikov, G.I. Fedorova, N.M. Sherykhalina, A.R. Urakov // Journal of Engineering Mathematics. - 2006. - V. 55, № 1-4. - P. 255-276.

19. Volgin, V. M. Modelling of Wire Electrochemical Machining / V.M. Volgin, V.D. Do, A.D. Davydov // Chemical Engineering Transactions. - 2014. - V. 41. - P. 91-96.

20. Volgin, V.M. Effect of Current Efficiency on Electrochemical Micromachining by Moving Electrode / V.M. Volgin, V.V. Lyubimov, I.V. Gnidina, A.D. Davydov, T.B. Kabanova // Procedia CIRP. - 2016. - V. 55. - P. 65-70.

21. Chen, Y. Multiphysics Simulation of the Material Removal Process in Pulse Electrochemical Machining (PECM) / Y. Chen, M. Fang, L. Jiang // International Journal of Advanced Manufacturing Technology. - 2017. - V. 91, № 5-8. - P. 2455-2465.

22. Zhitnikov, V.P. Exact Solutions of Two Limiting Quasistationary Electrochemical Shaping Problems / V.P. Zhitnikov, E.M. Oshmarina, G.I. Fedorova // Russian Mathematics. 2010. - V. 54, № 10. - P. 67-70. 
23. Zhitnikov, V.P. The Use of Discontinuous Functions for Modeling the Dissolution Process of Steady-State Electrochemical Shaping / V.P. Zhitnikov, E.M. Oshmarina, G.I. Fedorova // Russian Mathematics. - 2011. - V. 55, № 12. - P. 16-22.

24. Лаврентьев, М.А. Методы теории функций комплексного переменного / М.А. Лаврентьев, Б.В. Шабат. - М.: Наука, 1987.

25. Henrici, P. Applied and computational complex analysis / P. Henrici. - New York: Wiley Classic Library, 1993.

26. Биркгоф, Г. Струи, следы и каверны / Г. Биркгоф, Э. Сарантонелло. - М.: Мир, 1964.

27. Zhitnikov, V.P. Problem of Reliability Justification of Computation Error Estimates / V.P. Zhitnikov, N.M. Sherykhalina, A.A. Sokolova // Mediterranean Journal of Social Sciences. - 2015. - V. 6, № 2. - P. 65-78.

28. Aitken, A.C. On Bernoulli's Numerical Solution of Algebraic Equations / A.C. Aitken // Proceedings of the Royal Society of Edinburgh. - 1926. - V. 46. - P. 289-305.

29. Richargson, L.F. The Deferred Approach to the Limit / L.F. Richargson, J.A. Gaunt // Philosophical Transactions of the Royal Society of London. - 1927. - V. 226. - P. 299-361.

30. Polubarinova-Kochina, P.Ya. Theory of Groundwater Movement / P.Ya. PolubarinovaKochina. - Princeton: Princeton University Press, 1962.

Владимир Павлович Житников, доктор физико-математических наук, профессор, кафедра «Вычислительная математика и кибернетика», Уфимский государственный авиационный технический университет (г. Уфа, Российская Федерация), zhitnik@mail.ru.

Наталия Михайловна Шерыхалина, доктор технических наук, доцент, кафедра «Вычислительная математика и кибернетика», Уфимский государственный авиационный технический университет (г. Уфа, Российская Федерация), n_sher@mail.ru.

Сергей Сергеевич Поречный, кандидат физико-математических наук, доцент, кафедра «Высокопроизводительные вычислительные технологии и системы», Уфимский государственный авиационный технический университет (г. Уфа, Российская Федерация), porechny@mail.ru.

Поступила в редакиию 15 апреля 2018 г. 